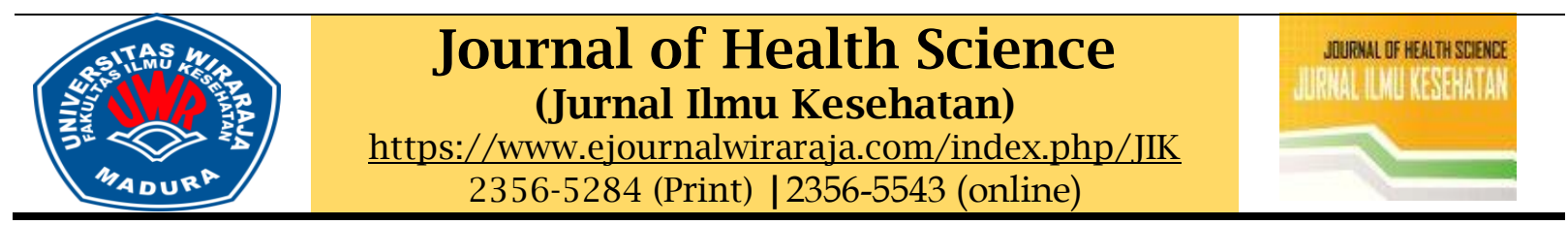

\title{
Keanekaragaman Manifestasi Klinis Pada Coronavirus Disease 2019 (COVID-19)
}

\author{
Budi Yanti ${ }^{1}$, T Andi Syahputra ${ }^{2}$, Fitri Amalia Rahma ${ }^{3}$, Rauzatil Aula Katuri ${ }^{4}$, Rosi Mega Safitri ${ }^{5}$ \\ ${ }^{1}$ Dept Pulmonologi dan Kedokteran Respirasi, Fakultas Kedokteran, Universitas Syiah Kuala, Banda Aceh \\ 2,3,4,5 Fakultas Kedokteran, Universitas Syiah Kuala, Banda Aceh \\ 'byantipulmonologis@unsyiah.ac.id*, \\ * corresponding author
}

\begin{tabular}{ll}
\hline Informasi artikel & ABSTRAK \\
\hline Received: 30-09-2020 & Coronavirus disease 2019 (COVID-19) disebabkan oleh SARS-CoV-2 dan \\
Revised: 04-112020 & saat ini menjadi masalah kesehatan masyarakat secara global. Penularan \\
Accepted: 10-11-2020 & penyakit ini selain melalui udara dapat juga menyebar melalui percikan \\
& ludah pada saat batuk dan bersin dari orang yang bergejala, atau orang \\
& tanpa gejala. Manifestasi klinis akibat infeksi virus ini sangat beragam dan \\
Kata kunci: & bergantung pada jumlah ekspresi reseptor ACE2 yang tersebar di seluruh \\
keanekaragaman, & tubuh manusia. Semakin banyak jumlah ekspresi di organ tersebut, akan \\
manifestasi klinis, & semakin sering pula keluhan yang timbul pada organ tersebut. Keluhan \\
Coronavirus & pada sistem pernafasan merupakan gejala yang paling sering ditemukan \\
disease (COVID-19), & diikuti dengan keluhan pada sistem penciuman seperti anosmia, keluhan \\
SARS CoV-2 & pada sistem penglihatan seperti konjungtivitis, keluhan pada sistem \\
& pencernaan seperti mual, muntah, dan diare, keluhan pada sistem \\
& vaskuler seperti trombosis dan emboli, dan keluhan pada sistem \\
& kardiovaskuler seperti Acute Cardiac Injury dan Acute Coronary \\
& Syndrome. Literatur review ini menggunakan metode mesin pencari \\
berbasis internet yang bertujuan untuk membahas tentang gangguan \\
fungsional pada sistem tubuh manusia sehingga menimbulkan \\
keanekaragaman manifestasi klinis pada COVID-19.
\end{tabular}

\section{Key word:}

Diversity, Symptoms,

COVID-19, SARS CoV-2

\begin{abstract}
Coronavirus disease 2019 (COVID-19) was caused by SARS-CoV-2 and is currently a global public health problem. This disease transmits through aerosols and saliva when coughing and sneezing from a person with symptoms or carrier people. The diversity of clinical manifestations would be detected and depended on the number of ACE2 receptor expressions that are scattered throughout the human body. The more expression in the organ, the more frequent symptoms that appear in the patient. The respiratory dysfunction is the most common symptoms that will be detected and followed by the olfactory dysfunction such as anosmia, the visual dysfunction such as conjunctivitis, the digestive dysfunction such as nausea, vomiting, and diarrhea, the vascular dysfunction such as thrombosis and embolism, and the cardiovascular dysfunction such as Acute Cardiac Injury and Acute Coronary Syndrome. This review literature used an internet-based search engine method that aims to discuss functional disorders in the human body system that caused diversity of clinical manifestations in COVID-19.
\end{abstract}

\section{Pendahuluan}

Coronavirus disease 2019 (COVID-19) pertama kali ditemukan di Kota Wuhan,Cina pada tanggal 31 Desember 2019 yang disebabkan oleh Severe acute respiratory syndrome coronavirus-2 (SARS-CoV-2). Awalnya ditemukan Pasien dengan keluhan ringan, sedang hingga berat dan sangat berat (kritis). Dapat ditemukan keluhan yang beraneka ragam dan terkadang tidak khas seperti nyeri kepala, demam (>38 C), batuk dan kesulitan bernapas. Keluhan lain yang menyertai seperti sulit bernafas, lemah, diare dan gejala saluran cerna lainya. Meskipun gejala yang paling sering ditemukan adalah keluhan pada sistem pernapasan, namun 
coronavirus juga ternyata dapat bereplikasi di enterosit sehingga menimbulkan manifestasi klinis seperti diare (Dong et al., 2020; PDPI, 2020; Zhang et al., 2020) (Yanti \& Hayatun, 2019). Lebih dari 16\% pasien mengalami sindroma gangguan pernapasan akut dengan rasio kematian sekitar 1-2\% (Rabaan et al., 2020).

Patogen penyebab penyakit ini awalnya disebut 2019 novel coronavirus (2019-nCoV) tetapi kemudian oleh WHO secara resmi dinamakan dengan Severe Acute Respirqtory Syndrome Coronavirus 2 (SARSCoV-2). Pada 30 Januari 2020, WHO menyatakan wabah SARS-CoV-2 sebagai Public Health Emergency of International Concern. Dibandingkan dengan SARS-CoV yang menyebabkan wabah SARS pada tahun 2003 di Guangdong, China dan MERS-CoV yang menyebabkan wabah pada tahun 2012 di Saudi Arabia. SARS-CoV-2 kurang patogen di banding SARS dan MERS. Struktur genom SARS -CoV-2 $75 \% \quad-80 \%$ identik dengan SARS-CoV, dan memiliki lebih banyak kemiripan dengan beberapa coronavirus lainnya yang berkembang biak pada kelelawar. Protein yang dikodekan oleh SARS-CoV-2, kelelawar-SL-CoVZC45, dan kelelawar-SL-CoVZXC21 hampir sama panjangnya. Satu-satunya perbedaan yang signifikan adalah protein S pada SARS-CoV2 lebih panjang dibandingkan dengan protein $\mathrm{S}$ yang dikodekan oleh kelelawar kelelawar-SL-CoVZC45, dan kelelawar-SLCoVZXC21 hampir sama panjangnya. Satusatunya perbedaan yang signifikan adalah protein S pada SARS-CoV-2 lebih panjang dibandingkan dengan protein $S$ yang dikodekan oleh kelelawar coronavirus, SARS-CoV, dan MERS-CoV (Lu et al., 2020) (Meyer et al., 2014).

Masa inkubasi pada COVID-19 selama 7-14 hari, SARS selama 2-7, dan MERS selama 5-6 hari. Gejala klinis yang ditimbulkan pada COVID-19 dan SARS memiliki banyak kesamaan, mulai dari demam, fatigue, batuk, myalgia, sesak napas, nyeri tenggorokan, diare, nause, pusing, nyeri kepala hingga muntah. MERS juga menimbulkan gejala klinis pada saluran napas berupa demam, batuk, nyeri tenggorokan dan nausea atau muntah. Tingkat kematian SARS berupa 10\% dan MERS 34,4\% (Meyer et al., 2014).

COVID-19 memiliki tingkat penyebaran yang sangat tinggi, virus ini bersifat zoonosis karena dapat diperantarai oleh hewan dan ditularkan ke manusia. Hewan seperti babi, sapi, kuda, kucing dan ayam juga beberapa hewan liar seperti kelelawar, tikus bambu, unta dan musang yang berfungsi sebagai host dan vektor penularan. Banyak referensi menunjukkan bahwa host alamiah coronavirus adalah kelelawar tapal kuda (horseshoe bars). Rute penularan coronavirus dimulai dari hewan ke manusia dan manusia ke manusia melalui kontak langsung, droplet, feses maupun oral (PDPI, 2020) (Yanti et al., 2020).

Coronavirus (CoV) adalah virus RNA yang menginfeksi hewan dan manusia dan digolongkan menjadi Alphacoronavirus, Betacoronavirus, Deltacoronavirus dan Gammacoronavirus. Terdapat tujuh jenis virus CoV seperti 229E dan NL63 (Genus Alphacoronavirus), OC43, HKU1, MERS dan SARS (Genus Betacoronavirus). Jenis 229E, NL63, OC43, dan HKU1 umumnya menginfeksi manusia dan menjadi penyebab wabah SARS dan MERS pada tahun 2002 dan 2012 dan menyebabkan kematian yang signifikan (Lu et al., 2020).

SARS CoV-2 memiliki beragam protein dengan fungsi yang berbeda. S protein adalah protein yang terletak di permukaan virus dan berfungsi untuk perlekatan pada host. Protein ini memiliki kekerabatan dengan virus HIV-1. Hubungan ini terdapat pada gp120 dan protein Gag HIV dengan glikoprotein spike SARS CoV-2. Protein ini sangat penting bagi virus untuk mengidentifikasi dan menempel pada sel inang dan kemudian melakukan replikasi. Karena protein permukaan ini bertanggung jawab atas setiap keunikan host tropisme. Perubahan protein ini menyiratkan adanya perubahan spesifisitas virus (Pradhan et al., 2020). Berikut ini beberapa ganguan pada sistem organ tubuh yang menimbulkan keanekaragaman manifestasi klinis pada COVID-19.

\section{Manifestasi Klinis Pada Sistem Vaskuler}

Penyakit Coronavirus 2019 (COVID-19) menjadi penyebab krisis kesehatan masyarakat secara global. Gejala pada system pernapasan sering ditemukan karena virus dapat berlekatan dengan sel inang yang mengekspresikan reseptor Angiotensin-Converting Enzyme 2 (ACE2) yang sangat berlimpah di paru. Sel endotel pada vaskuler juga mengekspresikan reseptor ACE2 , sehingga pada beberapa pasien COVID19 dapat ditemukan gangguan 
klinis seperti tekanan darah tinggi, trombosis, emboli paru (Sardu et al., 2020).

Disfungsi endotel mengacu pada suatu kondisi sistemik di mana endotelium kehilangan sifat fisiologis, termasuk kecenderungan terjadi vasodilatasi, fibrinolisis, dan pengenceran darah. Jaringan paru memiliki aktivitas Renin Angiotensin Aldosterone System (RAS) yang tinggi dan merupakan tempat utama sintesis Angiotensin II (Ang II) yang bersifat vasokonstriktor vaskuler paru. RAS akan menjadi aktif selama hipoksia. Ang II tidak hanya dapat memicu respon pertumbuhan sel otot polos di pembuluh darah tetapi juga dapat menyebabkan terjadinya remodeling pembuluh darah dan pirau yang berkahir dengan $t$ dengan cedera paru. Ang II juga dapat memicu edema paru dan merusak fungsi paru (Cheng et al., 2020; Sardu et al., 2020).

ACE2 memainkan peran penting pada aktivitas RAS. Ang II memicu aterosklerosis pada sistem kardiovaskular, peradangan, stres oksidatif, dan migrasi sel-sel endotel dan sel otot polos pembuluh darah (Sardu et al., 2020), karena ACE2 menyediakan jalur bagi SARS-CoV-2 untuk menyerang tubuh, ACE2 memungkinkan seseorang rentan terinfeksi. Prognosis COVID-19 derajat berat berhubungan dengan penurunan aktivitas ACE2 pada usia lanjut disertai dengan penyakit kronis yang mendasarinya. Infeksi SARS-CoV-2 mengurangi aktivitas ACE2 dan semakin memperburuk mekanisme ketidakseimbangan regulasi Ang II / ACE2 (Cheng et al., 2020).

\section{Manifestasi Klinis Pada Sistem Gastrointestinal}

Gangguan gastrointestinal yang paling umum ditemukan pada COVID-19 adalah mual/muntah dan diare, dengan prevalensi masing-masing 5,0\% dan 3,8\%. SARS-CoV-2 dapat menyebabkan infeksi pada sistem pencernaan karena pelepasan virus di usus lebih banyak dan bertahan lebih lama dari pada saluran pernapasan. Sehingga menimbulkan gejala gastrointestinal dan memungkinkan terjadinya penularan COVID-19 melalui fecal-oral (Dong et al., 2020).

Pada saluran cerna dan enterosit usus halus ditemukan ekspresi ACE-2 yang tinggi di permukaan saluran cerna sehingga rentan terjadinya peradangan. pada saat inflamasi ditemukan Infiltrat pada sel-sel plasma dan limfosit di lamina propria duodenum dan rectum disertai dengan edema interstisial tanpa merusak epitel mukosa (Zhang et al., 2020).

SARS CoV-2 juga bereplikasi di usus halus sehingga RNA virus terdeteksi pada sampel tinja pasien. ACE-2 berperan sebagai transporter asam amino, homeostasis asam amino, kekebalan bawaan, dan memelihara mikrobiota di usus sehingga kejadian malnutrisi dipikirkan kemungkinan adanya peradangan usus melalui ACE-2. (Zhang et al., 2020).

Mekanisme lain yang dapat terjadi adalah respon inflamasi sistemik yang terjadi pada pasien COVID-19. Infeksi COVID-19 dapat berkembang menjadi kondisi Systemic Inflammatory Response Syndrome (SIRS) dimana badai sitokin dapat secara langsung menyebabkan kerusakan pada epitel usus. Pada hepar kerusakan langsung yang disebabkan oleh virus juga dapat diperparah dengan antibody dependent enchancement of infection (ADE) dimana interaksi antibodi spesifik virus dengan Fc reseptor malah justru meningkatkan kemampuan virus memasuki granulosit, monosit dan makrofag (Behzad et al., 2020)

\section{Manifestasi Klinis Pada Sistem Penciuman}

Perhimpunan Telinga, Hidung, dan Tenggorokan Inggris dan Lembaga Rhinologi Inggris menegaskan bahwa terdapat hubungan antara infeksi SARS CoV-2 dengan anosmia / hiposmia berdasarkan dari berbagai laporan kasus pasien COVID19. Laporan ini lebih lanjut menyatakan bahwa individu dengan anosmia onset baru harus melakukan isolasi mandiri berdasarkan dugaan terinfeksi SARS-CoV-2. American Academy of Otolaryngology mengusulkan bahwa anosmia, Hiposmia dan dysgeusia (tanpa adanya penyakit pernapasan lainnya) harus dipikirkan kemungkinan sebagai gejala tambhan pada skrining infeksi SARS-CoV-2, sehingga masyarakat dapat segera melakukan isolasi sebagai pencegahan penularan penyakit secara dini (Brann et al., 2020).

Terjadinya disfungsi bau pada infeksi virus bukan hal baru dalam otolaringologi. Banyak virus dapat menyebabkan disfungsi penciuman atau Olfactory Disorder (OD) melalui reaksi inflamasi pada mukosa hidung dan rhinorrhea. Beberapa patogen yang paling dikenal penyebab anosmia seperti rhinovirus, parainfluenza Epstein- 
Barr virus, dan beberapa coronavirus. Akan tetapi disfungsi penciuman pada infeksi COVID-19 diduga tidak berhubungan dengan rhinorrhea (Lechien et al., 2020).

Strain coronavirus sebelumnya telah terbukti menyerang sistem saraf pusat melalui neuroepithelium penciuman kemudian menyebar di seluruh sistem penciuman. Sel-sel epitel hidung juga memiliki reseptor ACE2 (Association, 2020). Gangguan penciuman timbul dikarenakan perubahan konduksi bau karena proses inflamasi, diduga SARS-CoV-2 menginfeksi dan merusak sel-sel dalam epitel hidung yang diperlukan untuk fungsi penciuman normal. SARS-CoV-2 menginfeksi sel melalui interaksi antara protein $\mathrm{S}$ dan protein ACE2 pada sel target; interaksi ini membutuhkan pembelahan protein $S$ oleh protease TMPRSS2 pada permukaan sel. Infeksi pada sel epitel di saluran pernapasan juga bertanggung jawab terhadap kejadian anosmia dan gangguan terkait persepsi bau pada pasien COVID-19 (Brann et al., 2020).

Banyak mekanisme yang memungkinkan virus dapat menggangu fungsi penciuman, termasuk penurunan dalam konduksi bau dan kerusakan primer pada epitel penciuman, hal ini juga disebabkan oleh disfungsi sentral dalam struktur penciuman. Coronavirus menyebar dari epitel hidung melewati cribriform plate dan piriform cortex bahkan tanpa adanya kerusakan olfactory ephitelium (OE) untuk mempengaruhi aktivitas penciuman dan menimbulkan defisit penciuman. Masih belum dapat dipahami sepenuhnya tentang infeksi SARS-CoV-2 yang dapat mempengaruhi struktur penciuman pusat, mengingat bahwa SARS-CoV-2 tidak mungkin secara langsung menginfeksi Olfactory Sensory Neurons (ONS) sebagai transporter sinyal melalui akson ke otak (Brann et al., 2020).

Coronavirus dapat dideteksi pada sekret hidung pasien dengan gangguan penciuman. Selain itu, pada pemeriksaan rhinometri akustik yang normal tidak menyingkirkan kemungkinan adanya gangguan penciuman, karena peradangan dan obstruksi di hidung bukan satu-satunya faktor etiologis yang mendasari gangguan penciuman pada infeksi virus (Lechien et al., 2020).

Dari sudut pandang biomolekul, virus dapat menginfeksi neuron perifer dan menggunakan mesin transportasi aktif untuk mengakses sistem saraf pusat. Hal ini ditunjukkan pada tikus transgenik yang diinfeksi SARS-CoV, virus ini dapat masuk ke otak melalui penyebaran transneuronal yang cepat dan mempengaruhi sistem penciuman. (Lechien et al., 2020).

Penelitian terbaru menunjukkan bahwa beberapa varian ACE2 dapat mengurangi mekanisme infeksi dengan protein S-SARS-CoV. Dapat dikatakan bahwa jumlah ekspresi ACE2 dalam jaringan yang berbeda menjadi penentu perbedaan kerentanan terhadap infeksi, keluhan penyakit, dan outcome penyakit itu sendiri COVID-19 (Lechien et al., 2020).

\section{Manifestasi Klinis Pada Sistem Kardiovaskuler}

Meskipun manifestasi klinis COVID-19 didominasi oleh gejala pernapasan, beberapa pasien memiliki kerusakan kardiovaskular yang berat. Sehingga memahami kerusakan yang disebabkan oleh SARS-CoV-2 pada sistem kardiovaskular dan mekanisme yang mendasari adalah yang paling penting, sehingga pengobatan pasien ini dapat tepat waktu dan efektif dan mortalitas berkurang (Dong et al., 2020; Huang, Wang, Li, Ren, Zhao, Hu, Zhang, Fan, $\mathrm{Xu}, \& \mathrm{Gu}, 2020$ ).

Angiotensin-converting enzyme 2 (ACE2) adalah ikatan membran aminopeptidase yang memiliki peran penting pada sistem kardiovaskular dan kekebalan tubuh. Kadar ACE2 dapat meningkat melalui inhibitor sistem reninangiotensin-aldosteron. Mengingat bahwa ACE2 adalah reseptor fungsional untuk SARS-CoV-2, keamanan dan efek potensial dari terapi antihipertensi dengan ACE inhibitor atau penghambat reseptor angiotensin pada pasien dengan COVID-19 harus dipertimbangkan dengan cermat. (Huang et al., 2020).

SARS-CoV-2 memiliki patogenisitas pada kerusakan miokard sehingga menyulitkan tatalaksana pasien secara menyeluruh. Miokard injury karena infeksi SARS-CoV-2 ditemukan pada 5 dari 41 pasien pertama yang didiagnosis dengan COVID-19 di Wuhan dengan peningkatan high-sensitivity cardiac troponin I (hs-cTnI) yakni $(>28 \mathrm{pg} / \mathrm{ml})$. Manifestasi gejala kardiovaskular sering ditemukan karena respons inflamasi sistemik dan gangguan sistem kekebalan tubuh selama proses infeksi berlangsung (Wang et al., 2020). 
Mekanisme acute miocardial injury yang disebabkan oleh infeksi SARS-CoV-2 sangat erat berhubungan dengan jumlah ekspresi ACE2 memicu respon sel T helper tipe 1 dan tipe 2 yang tidak seimbang sehingga menghasilkan badai sitokin disfungsi pernapasan, hipoksemia berat dan semakin menambah kerusakan sel miokard (Alhogbani, 2016).

Pada infeksi SARS-CoV ditemukan 68\% pasien memiliki hiperlipidemia, $44 \%$ memiliki kelainan sistem kardiovaskular dan 60\% memiliki kelainan metabolisme glukosa. Hal ini terjadi karena disregulasi metabolisme lipid menyebabkan konsentrasi serum asam lemak bebas, secara signifikan meningkat dibandingkan dengan individu tanpa riwayat infeksi SARSCoV. Hal ini dipikirkan kemungkinan dapat terjadi pada pasien COVID19 (Wu et al., 2017).

Dalam satu penelitian pada pasien dengan gejala COVID-19 berat diantaranya 58\% memiliki hipertensi, 25\% memiliki penyakit jantung dan $44 \%$ memiliki aritmia (Wang et al., 2020). Menurut data kematian yang dirilis oleh New Hanover County (NHC), 35\% pasien dengan infeksi SARS-CoV-2 memiliki riwayat hipertensi dan 17\% memiliki riwayat penyakit jantung koroner. Pasien berusia $>60$ tahun yang terinfeksi SARS-CoV-2 umumnya memiliki gejala sistemik dan pneumonia yang lebih berat daripada pasien yang berusia $<60$ tahun (Chan et al., 2020). Oleh karena itu, pada pasien dengan infeksi SARS-CoV-2, adanya penyakit kardiovaskuler yang mendasari dapat memperburuk pneumonia dan meningkatkan keparahan gejala (Badawi \& Gwan, 2016; Badawi \& Ryoo, 2016; Chan et al., 2020; Wu et al., 2017).

Pasien dengan Acute Coronary Syndrome (ACS) yang terinfeksi dengan SARS-CoV-2 umumnya memiliki prognosis yang buruk karena cadangan fungsional jantung berkurang disebabkan iskemia atau nekrosis miokard. Beberapa pasien dengan COVID-19 di Wuhan yang memiliki Riwayat ACS sebelumnya, menderita pneumonia berat dan mortalitas tinggi. Banyak obat antivirus dapat menyebabkan insufisiensi jantung, aritmia atau gangguan kardiovaskular lainnya. Oleh karena itu, selama pengobatan COVID-19, terutama penggunaan obat antivirus, risiko toksisitas jantung harus dipantau secara ketat (Sakabe et al., 2013).

\section{Manifestasi Klinis Pada Sistem Penglihatan}

SARS-CoV-2 dapat menyebabkan peradangan konjungtiva yang melapisi bagian dalam kelopak mata dan menutupi bagian putih mata, menyebabkan kemerahan dan gatal di mata. Hubungan interaksi patologi antara infeksi SARS-CoV2 dan konjungtivitis juga belum jelas. Namun demikian, diperlukan penelitian lebih lanjut untuk memahami kemungkinan manifestasi sistem penglihatan, kemungkinan konjungtivitis virus untuk mengenali manifestasi awal COVID-19 dan menyarankan agar tetap waspada. Meskipun iritasi seperti konjungtivitis jarang mengganggu penglihatan dan dapat menghilang sendiri (Scalinci \& Trovato, 2020).

Dari 38 pasien COVID-19 yang dirawat di rumah sakit, sepertiga memiliki gangguan sistem penglihatan, seperti hiperemia konjungtiva, kemosis, epifora, dan peningkatan produksi sekret. Manifestasi gangguan sistem penglihatan sebagian besar pada COVID19 derajat sedang dan pada pasien dengan pneumonia berat (Martinc et al., 2020)

Selain itu, Berdasarkan pemeriksaan swab Polimerase Chain Reaction (PCR) dari konjungtiva ditemukan hanya 5\% dari pasien dengan gangguan sistem penglihatan terbukti positif SARS-CoV-2, Hal ini karena viral load yang rendah atau di bawah ambang batas deteksi teknik diagnosis PCR yang ada pada sekret dan air mata konjungtiva. (Martinc et al., 2020)

Manifestasi gangguan sistem penglihatan pada COVID-19 dan penularan melalui mata sering diabaikan oleh masyarakat umum, sebaiknya tetap harus waspada karena mata sebagai sumber infeksi yang penting dalam proses penularan penyakit ini. Permukaan mata juga menjadi host tropisme pada infeksi coronavirus yang serupa dengan saluran pernapasan. Oleh karena itu menutup mata dengan kacamata atau pelindung wajah harus dianggap sama pentingnya dengan memakai masker dan sarung tangan (Scalinci \& Trovato, 2020) (Yanti et al., 2020).

\section{Kesimpulan}

COVID-19 merupakan penyakit yang disebabkan oleh virus SARS-CoV-2 yang sangat menular dan menjadi kasus kegawatdarurata $n$ penyakit di seluruh 
dunia. Keluhan pada sistem pernapasan merupakan manifestasi klinis yang paling sering ditemukan pada pasien COVID-19. Hal ini tentu saja disebabkan jumlah ekspresi reseptor ACE2 yang berlimpah di saluran napas dan paru. Manifestasi klinis lainnya yang dapat ditemukan seperti keluhan gastrointestinal, keluhan penciuman, keluhan kardiovaskuler dan keluhan pada penglihatan. Manifestasi klinis yang beragam ini dapat muncul secara bersamaan pada COVID-19. Sehingga sangat diperlukan pemahaman yang luas terkait keanekaragaman manifestasi klinis COVID19 agar dapat membantu pengendalian peenularan penyakit dan penegakkan diagnosis COVID-19.

\section{Daftar Pustaka}

Alhogbani, T. (2016). Acute myocarditis associated with novel Middle East respiratory syndrome coronavirus. Annals of Saudi Medicine, 36, 78-80. https://doi.org/10.5144/02564947.2016.78

Association, A. M. (2020). Alterations in Smell or Taste in Mildly Symptomatic Outpatients With SARS-CoV-2 Infection. Journal American Medical Association., $\quad 1-2$. https://doi.org/10.1093/cid/ciaa330

Badawi, A., \& Gwan, S. (2016). International Journal of Infectious Diseases Prevalence of comorbidities in the Middle East respiratory syndrome coronavirus ( MERS-CoV ): a systematic review and meta-analysis. International Journal of Infectious Diseases, 49(January), 129-133. https://doi.org/10.1016/j.ijid.2016.06 .015

Badawi, A., \& Ryoo, S. G. (2016). Prevalence of comorbidities in the Middle East respiratory syndrome coronavirus (MERS-CoV): a systematic review and meta-analysis. International Journal of Infectious Diseases, 49, 129-133. https://doi.org/https://doi.org/10.10 16/j.ijid.2016.06.015

Behzad, S., Aghaghazvini, L., Radmard, A. R., \& Gholamrezanezhad, A. (2020). Extrapulmonary manifestations of COVID-19: Radiologic and clinical overview. In Clinical Imaging (Vol. 66, pp. 35-41). Elsevier Inc. https://doi.org/10.1016/j.clinimag.20 20.05.013
Brann, D., Tsukahara, T., \& Weinreb, C. (2020). Non-neural expression of SARS$\mathrm{CoV}-2$ entry genes in the olfactory epithelium suggests mechanisms underlying anosmia in COVID-19 patients. BioRxiv, 1(1), 1-25.

Burhan, E., Isbaniah, F., Susanto, A., Yoga, Y., Tjandra, A., Sugiri, T., \& Tantular, R. (2020). Pneumonia COVID-19 Diagnosis \& Penatalaksanaan di Indonesia. Perhimpunan Dokter Paru Indonesia (PDPI).

Chan, J. F.-W., Yuan, S., Kok, K.-H., To, K. K.W., Chu, H., Yang, J., Xing, F., Liu, J., Yip, C. C.-Y., Poon, R. W.-S., Tsoi, H.-W., Lo, S. K.-F., Chan, K.-H., Poon, V. K.-M., Chan, W.-M., Ip, J. D., Cai, J.-P., Cheng, V. C.-C., Chen, H., ... Yuen, K.-Y. (2020). A familial cluster of pneumonia associated with the 2019 novel coronavirus indicating person-toperson transmission: a study of a family cluster. The Lancet, 395(10223), 514-523.

https://doi.org/https://doi.org/10.10 16/S0140-6736(20)30154-9

Cheng, H., Wang, Y., \& Wang, G.-Q. (2020). Organ-protective Effect of Angiotensinconverting Enzyme 2 and its Effect on the Prognosis of COVID-19. Journal of Medical Virology, 92. https://doi.org/10.1002/jmv.25785

Dong, X., Cao, Y., Lu, X., Zhang, J., Du, H., Yan, Y., Akdis, C. A., \& Gao, Y. (2020). Eleven faces of coronavirus disease 2019. Allergy, $n / a(\mathrm{n} / \mathrm{a})$. https://doi.org/10.1111/all.14289

Huang, C., Wang, Y., Li, X., Ren, L., Zhao, J., Hu, Y., Zhang, L., Fan, G., Xu, J., \& Gu, X. (2020). Articles Clinical features of patients infected with 2019 novel coronavirus in Wuhan, China. 6736(20), 1-10. https://doi.org/10.1016/S01406736(20)30183-5

Huang, C., Wang, Y., Li, X., Ren, L., Zhao, J., Hu, Y., Zhang, L., Fan, G., Xu, J., Gu, X., Cheng, Z., Yu, T., Xia, J., Wei, Y., Wu, W., Xie, X., Yin, W., Li, H., Liu, M., ... Cao, B. (2020). Clinical features of patients infected with 2019 novel coronavirus in Wuhan, China. The Lancet, 395(10223), 497-506. https://doi.org/10.1016/S01406736(20)30183-5

Lechien, J., Estomba, C., De Siati, R. D., 
Horoi, M., Le Bon, S.-D., Rodriguez, A., Dequanter, D., Blecic, S., Afia, F., Distinguin, L., Chekkoury-Idrissi, Y., Hans, S., Delgado, I., Calvo-Henriquez, C., Lavigne, P., Falanga, C., Barillari, M. R., Cammaroto, G., Khalife, M., \& Saussez, S. (2020). Olfactory and gustatory dysfunctions as a clinical presentation of mild-to-moderate forms of the coronavirus disease (COVID-19): a multicenter European study. European Archives of Oto-RhinoLaryngology, 277. https://doi.org/10.1007/s00405-02005965-1

Lu, R., Zhao, X., Li, J., Niu, P., Yang, B., Wu, H., Wang, W., Song, H., Huang, B., Zhu, N., Bi, Y., Ma, X., Zhan, F., Wang, L., Hu, T., Zhou, H., Hu, Z., Zhou, W., Zhao, L., ... Tan, W. (2020). Genomic characterisation and epidemiology of 2019 novel coronavirus: implications for virus origins and receptor binding. The Lancet, 395(10224), 565-574. https://doi.org/10.1016/S01406736(20)30251-8

Martinc, D., Bremond, G., \& Daruich, D. (2020). Ocular manifestation as first sign of Coronavirus Disease 2019 (COVID-19): Interest of telemedicine during the pandemic context. Journal Français d'Ophtalmologie. https://doi.org/https://doi.org/10.10 16/j.jfo.2020.04.002

Meyer, B., Müller, M., Corman, V., Reusken, C., Ritz, D., Godeke, G.-J., Lattwein, E., Kallies, S., Siemens, A., van Beek, J., Drexler, J., Muth, D., Bosch, B. J., Wernery, U., Koopmans, M., Wernery, R., \& Drosten, C. (2014). Antibodies against MERS Coronavirus in Dromedary Camels, United Arab Emirates, 2003 and 2013. Emerging Infectious Diseases, 20, 552-559. https://doi.org/10.3201/eid2004.1317 46

Pradhan, P., Pandey, A., Mishra, A., Gupta, P., Tripathi, P., Menon, M., Gomes, J., Perumal, V., \& Kundu, B. (2020). Uncanny similarity of unique inserts in the 2019-nCoV spike protein to HIV-1 gp120 and Gag. https://doi.org/10.1101/2020.01.30.9 27871

Rabaan, A., Al-Ahmed, S., Haque, S., Sah, R., Tiwari, R., Malik, Y., Dhama, K., Yatoo, D. M., Bonilla-Aldana, D., \& RodriguezMorales, A. (2020). SARS-CoV-2, SARS-
CoV, and MERS-CoV: a comparative overview. Le Infezioni in Medicina: Rivista Periodica Di Eziologia, Epidemiologia, Diagnostica, Clinica e Terapia Delle Patologie Infettive, 28, 174-184.

Sakabe, M., Yoshioka, R., \& Fujiki, A. (2013). Sick sinus syndrome induced by interferon and ribavirin therapy in a patient with chronic hepatitis C. Journal of Cardiology Cases, 8(6), 173175.

https://doi.org/https://doi.org/10.10 16/j.jccase.2013.08.002

Sardu, C., Gambardella, J., \& Morelli, M. B. (2020). Is COVID-19 an endothelial disease? Clinical and basic evidence. April, $1-26$. https://doi.org/10.20944/preprints20 2004.0204.v1

Scalinci, S. Z., \& Trovato, B. E. (2020). Conjunctivitis can be the only presenting sign and symptom of COVID-19. IDCases, 20, e00774. https://doi.org/https://doi.org/10.10 16/j.idcr.2020.e00774

Wang, D., Hu, B., Hu, C., Zhu, F., Liu, X., Zhang, J., Wang, B., Xiang, H., Cheng, Z., Xiong, Y., Zhao, Y., Li, Y., Wang, X., \& Peng, Z. (2020). Clinical Characteristics of 138 Hospitalized Patients with 2019 Novel Coronavirus-Infected Pneumonia in Wuhan, China. JAMA - Journal of the American Medical Association, 323(11), 1061-1069.

https://doi.org/10.1001/jama.2020.15 85

Wu, Q., Zhou, L., Sun, X., Yan, Z., Hu, C., Wu, J., Xu, L., Li, X., Liu, H., Yin, P., Li, K., Zhao, J., Li, Y., Wang, X., Li, Y., Zhang, Q., Xu, G., \& Chen, H. (2017). Altered Lipid Metabolism in Recovered SARS Patients Twelve Years after Infection. Scientific Reports, 7. https://doi.org/10.1038/s41598-01709536-z

Yanti, B., \& Hayatun, U. (2019). Peran pemeriksaan radiologis pada diagnosis Coronavirus disease 2019. Jurnal Kedokteran Syiah Kuala Volume, 20(1), 53-57.

Yanti, B., Wahyudi, E., Wahiduddin, W., Novika, R. G. H., Arina, Y. M. D., Martani, N. S., \& Nawan, N. (2020). Community Knowledge, Attitudes, and Behavior Towards Social Distancing Policy As Prevention Transmission of 
Covid-19 in Indonesia. Jurnal Administrasi Kesehatan Indonesia, 8(2), 4. https://doi.org/10.20473/jaki.v8i2.20 20.4-14

Zhang, H., Li, H.-B., Lyu, J.-R., Lei, X.-M., Li, W., Wu, G., Lyu, J., \& Dai, Z.-M. (2020). Specific ACE2 expression in small intestinal enterocytes may cause gastrointestinal symptoms and injury after 2019-nCoV infection. International Journal of Infectious Diseases, $\quad 96, \quad 19-24$. https://doi.org/https://doi.org/10.10 16/j.ijid.2020.04.027 